\title{
Analisis Penerimaan Sistem Informasi K-Exam Karate Lemkari di Lemkari Sumatera Selatan Dengan Menggunakan Technology Acceptance Model
}

\author{
Maya Sapta Rina Pratama1, Rusmala Santi2, Fenando*3 \\ 1,2,3Program Studi Sistem Informasi, UIN Raden Fatah Palembang, Indonesia \\ Email: mayasaptaa@gmail.com¹ , rusmalasanti_uin@radenfatah.ac.id², \\ fenando_uin@radenfatah.ac.id ${ }^{3}$
}

\begin{abstract}
This study aims to determine the level of acceptance of the K-Exam Lemkari karate system in Lemkari, South Sumatra by using the Technology Acceptance Model (TAM) method. This study uses all the variables in the TAM model. The data in this study were collected using a questionnaire distributed to 236 respondents consisting of black belts and brown belts of Lemkari karate in the cities of Palembang. Muara Enim and Baturaja. Data analysis was performed using simple regression analysis. The results of this study indicate the acceptance rate of the K-Exam system is $73.178 \%$. From this percentage, it can be concluded that the K-Exam system is acceptable and has been used by respondents, namely black belts and brown karate belts. As well as the variable perceived ease of use and attitudes towards using technology have a major effect on the acceptance of the K-Exam information system. The higher the perceived ease of use and attitudes towards using technology, the higher the behavior of using the K-Exam Karate Lemkari information system in Lemkari, South Sumatra.
\end{abstract}

Keywords: K-Exam, TAM, Questionnaire, Simple Regression Analysis

\section{PENDAHULUAN}

Penerimaan teknologi informasi menjadi syarat utama kesuksesan implementasi teknologi informasi. Akan tetapi, seringkali suatu peningkatan kinerja tidak tercapai karena ketidaksediaan pengguna (user) untuk menerima dan menggunakan sistem yang ada. Karena pentingnya masalah ini, penjelasan tentang penerimaan teknologi informasi telah menjadi isu yang sudah lama diteliti dalam bidang manajemen sistem informasi.

Berbagai teori untuk mengukur perilaku penerimaan teknologi informasi seperti Theory of Reasoned Action (TRA) oleh Fishbein dan Ajzen (1975) yang 
merupakan teori perilaku manusia yang paling mendasar dan berpengaruh. Teori ini sudah banyak diterapkan diberbagai bidang, termasuk pemasaran, sistem informasi dan lainnya, Technology Acceptance Model (TAM) oleh Davis et al. (1989)

Davis et al. (1989) menawarkan TAM sebagai sebuah model untuk menjelaskan penerimaan sistem teknologi informasi yang akan digunakan oleh pemakai serta untuk mengetahui faktor-faktor penyebab orang menerima atau menolak teknologi informasi. Salah satu model penerimaan teknologi yang sesuai dengan masalah yang ada di Lemkari Sumatera Selatan adalah TAM. Karena TAM mempunyai kelebihan untuk menjawab pertanyaan mengapa banyak sistem teknologi informasi gagal diterapkan karena pemakai tidak mempunyai niat untuk menggunakannya. Di dalam model TAM memiliki lima variabel yaitu kegunaan persepsian, kemudahan penggunaan persepsian, sikap terhadap menggunakan teknologi, minat perilaku menggunakan teknologi dan penggunaan teknologi sesungguhnya.

Lemkari Sumatera Selatan merupakan salah satu organisasi karate terbesar di Sumatera Selatan yang telah menerapkan sistem informasi managemen online sejak tahun 2017 sistem informasi K-Exam diterapkan di daerah Sumatera Selatan yaitu kota Palembang, kabupaten Komering Ulu Timur, kabupaten komering Ulu, Kabupaten Muara Enim, Kota Prabumulih, kabupaten Komering Ulu Selatan, kabupaten Empat Lawang, dan kabupaten Lahat.

Beberapa fitur yang dapat di akses dan digunakan di sistem informasi K-Exam antara lain pendaftaran form registrasi dojo, Pendaftaran murid baru, jadwal kegiatan ujian kyu karate, cek ijazah sabuk/turun kyu, peserta ujian kyu setiap semester berdasarkan jenis sabuk, peserta ujian kyu setiap semester berdasarkan kelompok usia, sebaran peserta ujian berdasarkan cabang, grafik jumlah peserta ujian, serta login penilaian kyu. Terkait dengan kepentingan managemen, suatu sistem informasi yang ada di organisasi perlu dievaluasi, salah satunya terhadap penerimaan sistem informasi K-Exam tersebut. Evaluasi ini penting dilakukan untuk mengetahui, memperhatikan dan menentukan langkah-langkah yang dibutuhkan selanjutnya terkait aspek penerimaan sistem informasi K-Exam di Lemkari Sumatera Selatan dalam menunjang kegiatan managemen.

Berdasarkan pembahasan tersebut, maka akan dilakukan penelitian tentang "Analisis Penerimaan Sistem Informasi K-Exam Karate Lemkari di Lemkari Sumsel Dengan Menggunakan Tecnology Acceptance Model". 


\section{METODE PENELITIAN}

Metode penelitian dalam penelitian ini adalah pendekatan kuantitatif dengan teknik pengumpulan data kuesioner, karena penelitian yang akan diteliti ini memberikan daftar pertanyaan kepada responden yaitu karate sabuk hitam dan sabuk coklat.

\subsection{Technology Acceptance Model}

Model penerimaan teknologi (Tehcnology Acceptance Model) merupakan suatu model penerimaan sistem teknologi informasi yang akan digunakan oleh pemakai untuk mengetahui sikap penerimaan pengguna terhadap hadirnya teknologi. Berdasarkan TRA, Davis et al. (1989) mengembangkan model penerimaan teknologi untuk mengetahui faktor-faktor penyebab orang menerima atau menolak teknologi informasi (Abdillah, 2018:63). Model TAM dapat dilihat pada gambar 1 .

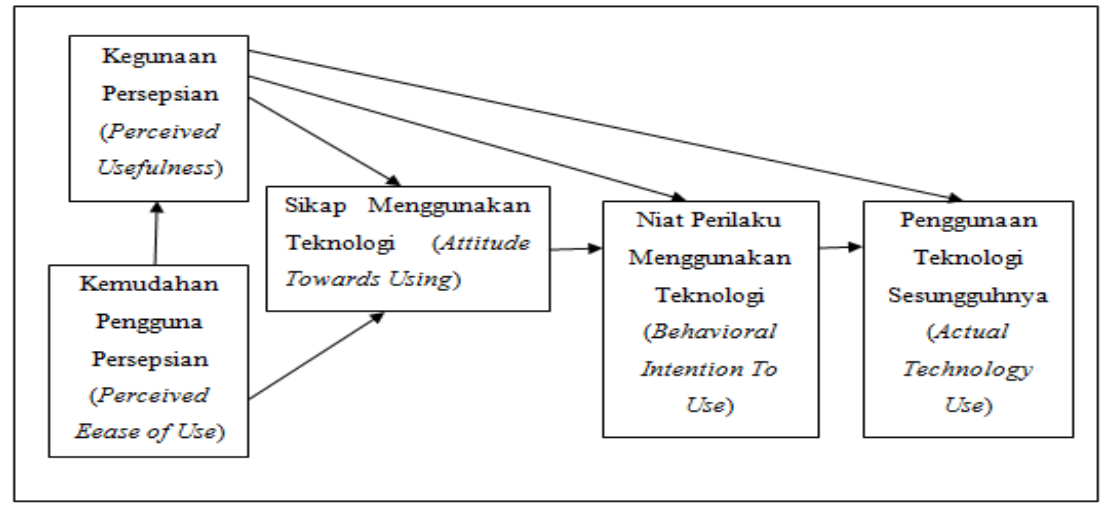

Gambar 1. Technology Acceptance Model

(Sumber: Prof. Jogiyanto HM., Akt., MBA., Ph.D. 2007:112)

\subsection{Populasi dan Sampel}

Pada penelitian ini populasinya adalah karate-ka sabuk hitam dan sabuk coklat di daerah kota Palembang, Muara Enim dan Baturaja. Berikut dijelaskan pada Tabel 1 jumlah populasi pada penelitian ini:

Tabel 1 Jumlah Populasi Penelitian

\begin{tabular}{lll}
\hline No. & Nama & Jumlah \\
\hline 1. & Sabuk Hitam & 114 \\
2. & Sabuk Coklat & 460 \\
Total & & 574 \\
\hline
\end{tabular}


Dengan menggunakan rumus Slovin, dari total populasi sebanyak 574 dengan tingkat signifikansi 5\% maka didapatkan jumlah sampel sebanyak 236 sampel. Berikut dijabarkan perhitungannya :

Diketahui

$$
\begin{gathered}
\quad N=574 ; \\
\mathrm{n}=\frac{N}{1+n e^{2}} \quad=\frac{574}{1+574(0,05)^{2}} \\
=\frac{574}{2,435}=235,72
\end{gathered}
$$

$$
=\frac{574}{1+574 \times 0,0025}
$$$$
=236 \text { Sampel }
$$

Menurut Sugiyono (2014:130) populasi berstrata, maka sampelnya juga berstrata. Sehingga teknik pengambilan sampel adalah Proportionade Stratified Random Sampling. Dalam penentuan sampel pada penelitian ini stratanya ditentukan berdasarkan kedudukan. Berikut dijelaskan perhitungannya:

$$
\begin{array}{ll}
\text { Sabuk Hitam } & =\frac{\text { jumlah populasi sabuk hitam }}{\text { total seluruhnya }} \times \text { Jumlah sampel } \\
& =\frac{114}{574} \times 236 \\
& =47 \text { sampel } \\
\text { Sabuk Coklat } \quad & =\frac{\text { jumlah populasi sabuk coklat }}{\text { total seluruhnya }} \times \text { Jumlah sampel } \\
& =\frac{460}{574} \times 236 \\
& =189 \text { sampel }
\end{array}
$$

Jadi jumlah sampelnya adalah 47 sampel dari sabuk hitam dan 189 sampel dari sabuk coklat sehingga total sampel 236 sampel. Dengan demikian masingmasing sampel untuk tingkat kedudukan harus proporsional sesuai dengan populasi.

\subsection{Kerangka Konseptual dan Hipotesis Penelitian}

\subsubsection{Kerangka Konseptual}

Penelitian ini melibatkan 5 (lima) variabel yaitu kegunaan, kemudahan penggunaan, sikap terhadap menggunakan teknologi, niat perilaku menggunakan teknologi, dan penggunaan teknologi sesungguhnya. Gambaran hubungan antar variabel yang diteliti terlihat pada gambar 2 di bawah ini. 


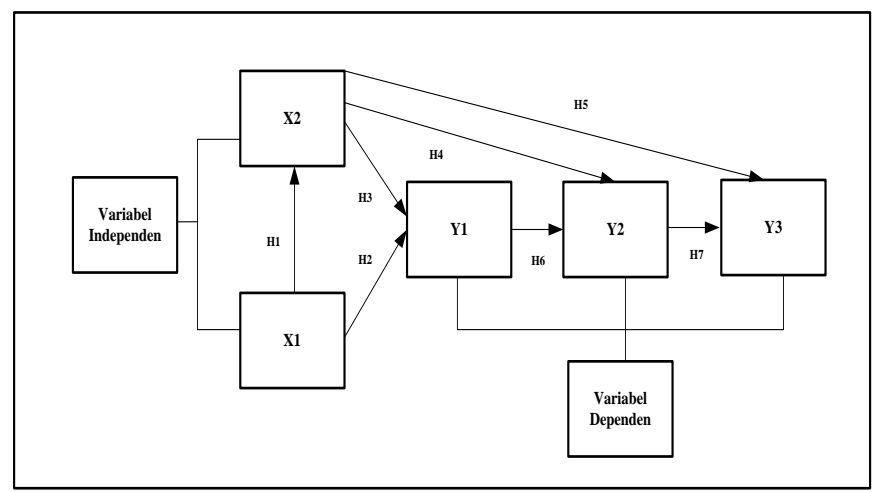

Gambar 2. Kerangka Konseptual

\subsubsection{Hipotesis Penelitian}

1. Ho : Kemudahan penggunaan persepsian tidak berpengaruh signifikan terhadap kegunaan persepsian.

$\mathrm{Ha}$ : Kemudahan penggunaan persepsian berpengaruh signifikan terhadap kegunaan persepsian.

2. Ho : Kemudahan penggunaan persepsian tidak berpengaruh signifikan terhadap sikap terhadap menggunakan teknologi

$\mathrm{Ha}$ : Kemudahan penggunaan persepsian berpengaruh signifikan terhadap sikap menggunakan teknologi.

3. Ho : Kegunaan persepsian tidak berpengaruh signifikan terhadap sikap menggunakan teknologi.

$\mathrm{Ha}$ : Kegunaan persepsian berpengaruh signifikan terhadap sikap menggunakan teknologi.

4. Ho : Kegunaan persepsian tidak berpengaruh signifikan terhadap minat perilaku menggunakan teknologi.

$\mathrm{Ha}$ : Kegunaan persepsian berpengaruh signifikan terhadap minat perilaku menggunakan teknologi.

5. Ho : Kegunaan persepsian tidak berpengaruh signifikan terhadap penggunaan teknologi sesungguhnya.

$\mathrm{Ha}$ : Kegunaan persepsian berpengaruh signifikan terhadap penggunaan teknologi sesungguhnya.

6. Ho : Sikap terhadap menggunakan teknologi tidak berpengaruh signifikan terhadap minat perilaku menggunakan teknologi.

$\mathrm{Ha}$ : Sikap terhadap menggunakan teknologi berpengaruh signifikan terhadap minat perilaku menggunakan teknologi.

7. Ho : Minat perilaku menggunakan teknologi tidak berpengaruh signifikan terhadap penggunaan teknologi sesungguhnya. 
$\mathrm{Ha}$ : Minat perilaku menggunakan teknologi berpengaruh signifikan terhadap penggunaan teknologi sesungguhnya.

\subsubsection{Tahapan Penelitian}

Tahapan penelitian yang dituangkan dalam diagram alir bahwa ini, menggambarkan proses penelitian yang akan ditempuh sekaligus menggambarkan penelitian secara keseluruhan. Tahapan penelitian yang ditempuh berdasarkan tahapan penelitian metode kuantitatif.

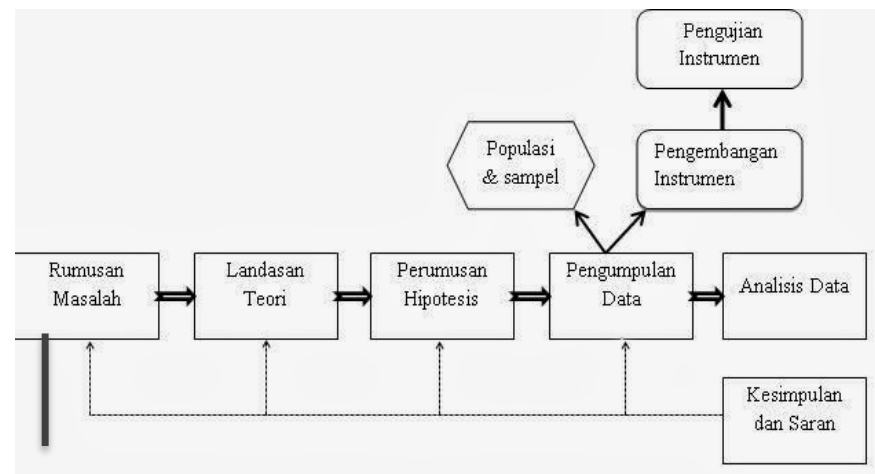

Gambar 3. Tahapan Penelitian (Sumber : Sugiyono, 2016:30)

\section{HASIL DAN PEMBAHASAN}

3.1 Deskripsi Responden

1. Responden Berdasarkan Asal Kota/Kabupaten

\section{RESPONDEN BERDASARKAN ASAL KOTA/KABUPATEN}

- Palembang Muara Enim Baturaja

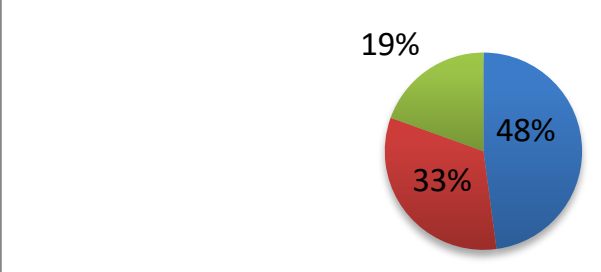

Gambar 4 Diagram Responden Berdasarkan Asal Kota/Kabupaten 
Berdasarkan Gambar 5 diketahui responden yang mengisi kuesioner penelitian ini mengenai sistem informasi K-Exam karate Lemkari di Lemkari Sumatera Selatan adalah dari kota Palembang sebanyak 113 orang atau jika dipersentasekan sebesar 48\%, dari kabupaten Muara Enim sebanyak 77 orang dan dipersentasekan sebesar sebesar 33\% dan kabupaten Baturaja sebanyak 46 orang dan dipersentasikan sebesar 19\%. Maka dapat disimpulkan bahwa hasil penelitian ini dipengaruhi oleh responden dari kota Palembang.

2. Responden Berdasarkan Tingkatan Sabuk

\section{RESPONDEN BERDASARKAN TINGKATAN SABUK}

Hitam Coklat

$80 \%$

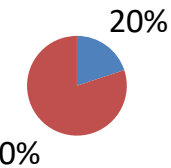

Gambar 5. Diagram Responden Berdasarkan Tingkatan Sabuk

Berdasarkan Gambar 5 diketahui hasil dari rekap data kuesioner berdasarkan tingkatan sabuk yaitu sabuk hitam sebanyak 47 orang dengan persentase sebesar 20\%, dan sabuk coklat sebanyak 189 orang dengan persentase sebesar $80 \%$. Dapat diambil kesimpulan tingkatan sabuk yang mendominasi dalam pengisian kuesioner adalah sabuk coklat sebanyak 189 orang dengan persentase 80\%.

3. Responden Berdasarkan Tingkatan DAN/KYU

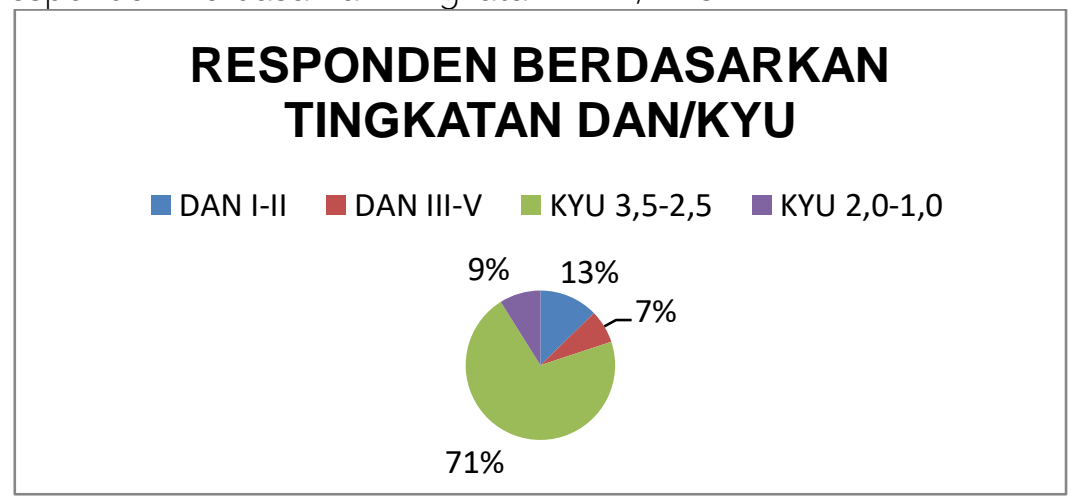

Gambar 6. Diagram Responden Berdasarkan Tingkatan DAN/KYU 
Berdasarkan Gambar 6. responden yang mengisi kuesioner penelitian berdasarkan tingkatan DAN/KYU yaitu DAN I-II sebanyak 30 orang dengan persentase sebesar $13 \%$, DAN III-V sebanyak 17 orang dengan persentase sebesar 7\%, KYU 3,5-2,5 sebanyak 168 orang dengan persentase sebesar $71 \%$ dan KYU 2,0-1,0 sebanyak 21 orang dengan persentase sebesar 9\%. Maka dapat disimpulkan bahwa hasil tingkatan DAN/KYU yang mendominasi pengisian kuesioner adalah KYU 3,5-2,5 sebanyak 168 orang dengan persentase sebesar $71 \%$.

4. Responden Berdasarkan Jenis Kelamin

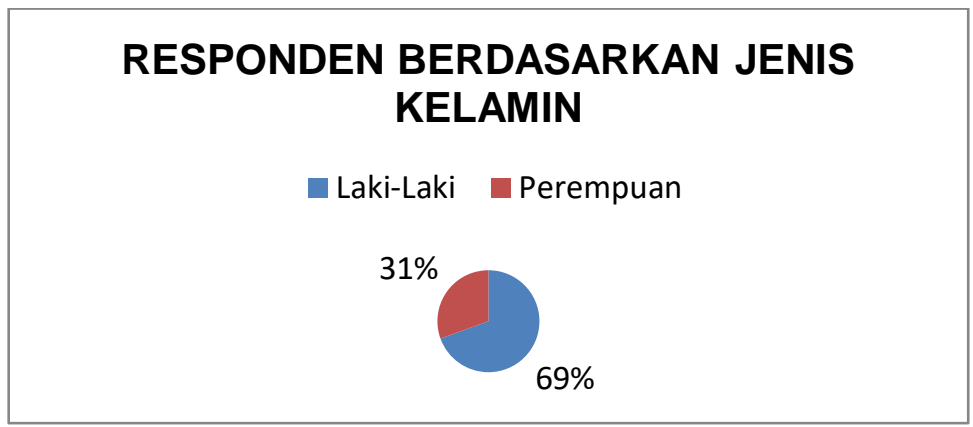

Gambar 7. Diagram Responden Berdasarkan Jenis Kelamin

Berdasarkan Gambar 7. responden yang mengisi kuesioner berdasarkan jenis kelamin adalah jenis kelamin laki-laki sebanyak 164 orang dengan persentase sebesar $69 \%$, dan jenis kelamin wanita sebanyak 72 orang dengan persentase sebesar 31\%. Dapat disimpulkan bahwa responden berdasarkan jenis kelamin yang lebih mendominasi adalah jenis kelamin laki-laki yaitu sebanyak 164 orang dengan persentase sebesar $69 \%$.

\subsection{Uji Validitas}

Uji validitas digunakan untuk mengukur sah atau tidaknya suatu kuesioner. Suatu kuesioner valid jika pertanyaan pada kuesioner mampu untuk mengungkapkan sesuatu yang akan diukur oleh kuesioner tersebut.

Tabel 1. Hasil Uji Validitas Kuesioner Variabel Kemudahan Penggunaan Persepsian (Perceived Ease of Use)

\begin{tabular}{lllll}
\hline Variabel & Pertanyaan & Koefisien Validitas & Titik Kritis & Keterangan \\
\hline & $X_{11}$ & 0,435 & 0,374 & valid \\
& $X_{12}$ & 0,716 & 0,374 & valid \\
& $X_{13}$ & 0,584 & 0,374 & valid \\
\hline
\end{tabular}


Journal of Information Technology Ampera

Vol. 1. No. 1, April 2020 e-ISSN: 2774-2121

https://journal-computing.org/index.php/journal-ita/index

\begin{tabular}{lllll}
\hline Variabel & Pertanyaan & Koefisien Validitas & Titik Kritis & Keterangan \\
\hline$X_{14}$ & 0,609 & 0,374 & valid \\
& $X_{15}$ & 0,804 & 0,374 & valid \\
& $X_{16}$ & 0,754 & 0,374 & valid \\
\hline
\end{tabular}

Tabel 2. Hasil Uji Validitas Kuesioner Variabel Kegunaan Persepsian (Perceived

\begin{tabular}{|c|c|c|c|c|}
\hline & \multicolumn{4}{|c|}{ Usefulnes) } \\
\hline Variabel & $\begin{array}{l}\text { Pertany } \\
\text { aan }\end{array}$ & $\begin{array}{l}\text { Koefisien } \\
\text { Validitas }\end{array}$ & $\begin{array}{l}\text { Titik } \\
\text { Kritis }\end{array}$ & $\begin{array}{l}\text { Keteran } \\
\text { gan }\end{array}$ \\
\hline \multirow{6}{*}{$\begin{array}{l}\text { Persepsi Kegunaan (Perceived } \\
\text { Usefulness) }\end{array}$} & $x_{21}$ & 0,885 & 0,374 & valid \\
\hline & $x_{22}$ & 0,899 & 0,374 & valid \\
\hline & $X_{23}$ & 0,779 & 0,374 & valid \\
\hline & $X_{24}$ & 0,661 & 0,374 & valid \\
\hline & $X_{25}$ & 0,734 & 0,374 & valid \\
\hline & $X_{26}$ & 0,906 & 0,374 & valid \\
\hline
\end{tabular}

Tabel 3. Hasil Uji Validitas Kuesioner Sikap Menggunakan Teknologi (Attitide Towards Using Technology)

\begin{tabular}{lllll}
\hline \multirow{2}{*}{ Variabel } & $\begin{array}{l}\text { Pertan } \\
\text { yaan }\end{array}$ & $\begin{array}{l}\text { Koefisien } \\
\text { Validitas }\end{array}$ & $\begin{array}{l}\text { Titik } \\
\text { Kritis }\end{array}$ & $\begin{array}{l}\text { Ketera } \\
\text { ngan }\end{array}$ \\
\hline & $Y_{11}$ & 0,711 & $\begin{array}{l}0,37 \\
4\end{array}$ & Valid \\
& & & 0,37 & \\
& $Y_{12}$ & 0,942 & 4 & Valid \\
Sikap Menggunakan Teknologi (Attitide & & & 0,37 & Valid \\
Towards Using Technology) & $Y_{13}$ & 0,909 & 4 & \\
& & & 0,37 & Valid \\
& $Y_{14}$ & 0,774 & 4 & \\
\hline
\end{tabular}

Tabel 4. Hasil Uji Validitas Kuesioner Variabel Niat Perilaku Pengguna (Behavioral Intention to Use)

\begin{tabular}{lllll}
\hline \multirow{2}{*}{ Variabel } & Pertany & Koefisien & Titik & Keteran \\
& aan & Validitas & Kritis & gan \\
\hline \multirow{2}{*}{$\begin{array}{l}\text { Niat Perilaku Pengguna } \\
\text { Intention To Use) }\end{array}$} & $Y_{21}$ & 0,667 & 0,374 & Valid \\
& $Y_{22}$ & 0,815 & 0,374 & Valid \\
& $Y_{23}$ & 0,794 & 0,374 & Valid \\
\hline
\end{tabular}




$\begin{array}{llll}Y_{24} & 0,641 & 0,374 & \text { Valid } \\ Y_{25} & 0,579 & 0,374 & \text { Valid }\end{array}$

Tabel 5. Hasil Uji Validitas Kuesioner Penggunaan Sesungguhnya (Actual

\begin{tabular}{|c|c|c|c|c|c|}
\hline \multirow{2}{*}{\multicolumn{2}{|c|}{ Variabel }} & \multicolumn{4}{|c|}{ echnology (use) } \\
\hline & & $\begin{array}{l}\text { Pertany } \\
\text { aan }\end{array}$ & $\begin{array}{l}\text { Koefisien } \\
\text { Validitas }\end{array}$ & $\begin{array}{l}\text { Titik } \\
\text { Kritis }\end{array}$ & $\begin{array}{l}\text { Keteran } \\
\text { gan }\end{array}$ \\
\hline \multirow{2}{*}{$\begin{array}{l}\text { Niat Perilaku } \\
\text { Intention to Use) }\end{array}$} & (Behavioral & $Y_{31}$ & 0,828 & 0,374 & Valid \\
\hline & & $Y_{32}$ & 0,891 & 0,374 & Valid \\
\hline
\end{tabular}

\subsection{Uji Reliabilitas}

Menurut Siregar (2013:55) Reliabilitas adalah untuk mengetahui sejauh mana hasil pengukuran tetap konsisten, apabila dilakukan pengukuran dua kali atau lebih terhadap gejala yang sama dengan menggunakan alat pengukur yang sama pula.

Tabel 6 Tabel Hasil Uji Reliabilitas

\begin{tabular}{llll}
\hline Kuisioner Variabel & $\begin{array}{l}\text { Koefisien } \\
\text { Reliabilitas }\end{array}$ & Nilai Kritis & Keterangan \\
\hline $\begin{array}{l}\text { Kemudahan Penggunaan } \\
\text { Persepsian (Perceived Ease Of }\end{array}$ & 0,722 & 0,6 & Reliabel \\
Use) & & & \\
$\begin{array}{l}\text { Kegunaan Persepsian (Perceived } \\
\text { Usefulnes) }\end{array}$ & 0,893 & 0,6 & Reliabel \\
$\begin{array}{l}\text { Sikap Terhadap Teknologi } \\
\text { (Attitude Towards Using }\end{array}$ & 0,855 & & \\
$\begin{array}{l}\text { Technology) } \\
\text { Niat Perilaku Pengguna }\end{array}$ & 0,743 & & Reliabel \\
(Behavioral Intention To Use) & & 0,6 & Reliabel \\
$\begin{array}{l}\text { Penggunaan Sesungguhnya } \\
\text { (Actual Technology Use) }\end{array}$ & 0,641 & 0,6 & Reliabel \\
\hline
\end{tabular}

Maka dapat disimpulkan bahwa instrumen penelitian pada variabel kemudahan penggunaan persepsian (perceived ease of use) dinyatakan reliabel, karena 
nilai $r_{11}=0,722>0,6$. Begitu juga untuk variabel lain di uji dengan langkah yang sama, dibantu dengan menggunakan program SPSS 22.

\subsection{Uji Asumsi Klasik}

1) Uji Normalitas

Pada penelitian ini metode yang digunakan untuk uji normalitas data adalah dengan metode grafik P-P Plot. Hasil dari pengujian uji normalitas dapat dilihat dari pada gambar 4.11. Dari grafik tersebut dapat diketahui bahwa titik-titik menyebar sekitar garis diagonal dan mengikuti arah garis diagonal, maka data terdistribusi dengan normal dan model regresi telah memenuhi asumsi normalitas.

\section{Normal P-P Plot of Regression Standardized Residual}

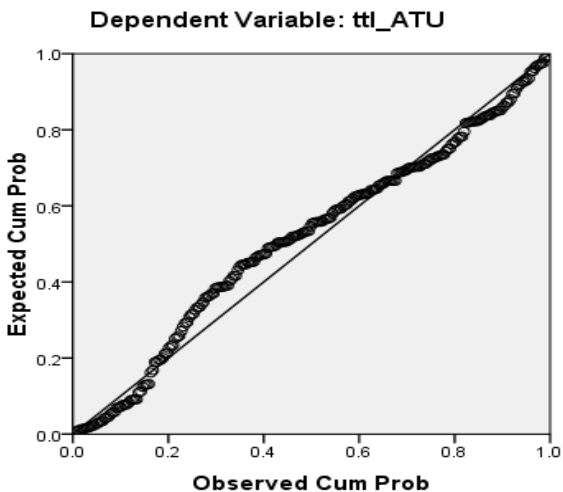

Gambar 8. Grafik Normal Probability Plot

2) Uji Multikolinieritas

Uji Multikolinieritas pada penelitian ini menggunakan metode VIF dan Tolerance. Berikut hasil uji multikolinearitas dari penelitian ini dapat dilihat pada Gambar 9.

Coefficients ${ }^{a}$

\begin{tabular}{|c|c|c|c|c|c|c|c|c|}
\hline \multirow{2}{*}{\multicolumn{2}{|c|}{ Madel }} & \multicolumn{2}{|c|}{ Unstandardized Coefficients } & \multirow{2}{*}{$\begin{array}{c}\begin{array}{c}\text { Standardized } \\
\text { Coefficients }\end{array} \\
\text { Beta }\end{array}$} & \multirow[b]{2}{*}{$t$} & \multirow[b]{2}{*}{ Siq. } & \multicolumn{2}{|c|}{ Collinearity Statistics } \\
\hline & & $B$ & Std. Error & & & & Tolerance & VIF \\
\hline \multirow[t]{5}{*}{1} & (Constant) & -.154 & .579 & & -.266 & .791 & & \\
\hline & $\mathrm{ttl} \_\mathrm{PEOU}$ & .010 & .035 & .026 & .296 & .768 & .326 & 3.069 \\
\hline & $\mathrm{ttl} \_\mathrm{PU}$ & .140 & .038 & .320 & 3.655 & .000 & .332 & 3.012 \\
\hline & $\mathrm{ttl}$ ATUT & .123 & .067 & .169 & 1.853 & .065 & .305 & 3.284 \\
\hline & ttl_BITU & .100 & .044 & .198 & 2.254 & .025 & .330 & 3.031 \\
\hline
\end{tabular}

a. Dependent Variable: ttI_ATU

Gambar 9. Uji Multikolinearitas (Sumber : data diolah dengan SPSS 22) 
3) Uji heteroskedastis

Berikut hasil pengujian dari uji heteroskedastisitas pada Gambar 10.

\section{Scatterplot}

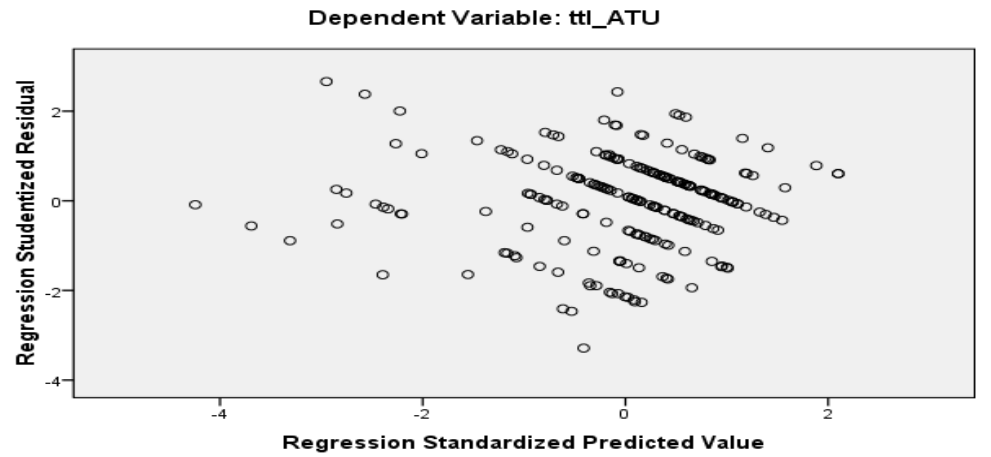

Gambar 10. Hasil Uji Heteroskedastisitas (Sumber : diolah dengan SPSS 22)

Dari Gambar 10. diatas dapat kita lihat tidak ada pola yang jelas dan titik-titiknya menyebar diatas dan dibawah angka $O$ pada sumbu $Y$, maka dapat dikatakan tidak terjadi heteroskedastisitas.

\section{4) Uji Autokorelasi}

Hasil dari penelitian uji autokorelasi ini menggunakan Durbin Watson, berikut hasilnya dapat dilihat pada Gambar 11

\section{Miodel Summary}

\begin{tabular}{|l|l|r|r|r|r|}
\hline \begin{tabular}{l} 
Mode \\
\hline 1
\end{tabular} & $\mathrm{R}$ & $\mathrm{R}$ Square & $\begin{array}{c}\text { Adjusted } \mathrm{R} \\
\text { Square }\end{array}$ & $\begin{array}{c}\text { Std. Error of } \\
\text { the Estimate }\end{array}$ & $\begin{array}{c}\text { Durbin- } \\
\text { Watson }\end{array}$ \\
\hline $1643^{3}$ & .413 & .403 & 1.343 & 1.998 \\
\hline
\end{tabular}

a. Predictors: (Constant), ttI_BITU, ttI_PEOU, ttI_PU, ttI_ATUT

b. Dependent Variable: $\mathrm{tt}$ _ATU

Gambar 11. Hasil Uji Durbin Watson (Sumber : diolah dengan SPSS 22)

Dari hasil Gambar 11. diatas diketahui nilai DW adalah sebesar 1,998 dan dari tabel Durbin Watson diketahui DU sebesar 1,819. Maka nilai DU lebih kecil dari DW $(1,819<1,998)$ dan kurang dari 4-DU $(4-1,819=2,181)$ yaitu dengan nilai 1,819 $<1,998<2,181$ sehingga dapat ditarik kesimpulan bahwa tidak terjadi autokorelasi. 


\subsection{Pengujian Hipotesis}

Berikut ini adalah hasil ringkasan pengujian hipotesis regresi sederhana :

Tabel 7 Hasil Pengujian Hipotesis Regresi Sederhana

\begin{tabular}{|c|c|c|c|c|c|}
\hline No & \multicolumn{2}{|c|}{ Hipotesis } & Thitung & Ttabel & Keputusan \\
\hline & $\mathrm{Ho}$ & $\begin{array}{l}\text { Kemudahan penggunaan } \\
\text { persepsian tidak berpengaruh } \\
\text { terhadap kegunaan persepsian }\end{array}$ & - & - & Ho ditolak \\
\hline 1. & $\mathrm{Ha}$ & $\begin{array}{l}\text { Kemudahan penggunaan } \\
\text { persepsian } \quad \text { berpengaruh } \\
\text { terhadap kegunaan persepsian }\end{array}$ & 12,850 & 1,968 & Ha diterima \\
\hline & $\mathrm{Ho}$ & $\begin{array}{l}\text { Kemudahan penggunaan } \\
\text { persepsian tidak berpengaruh } \\
\text { terhadap sikap terhadap } \\
\text { menggunakan teknologi }\end{array}$ & - & - & Ho ditolak \\
\hline 2. & $\mathrm{Ha}$ & $\begin{array}{l}\text { Kemudahan penggunaan } \\
\text { persepsian } \quad \text { berpengaruh } \\
\text { terhadap sikap terhadap } \\
\text { menggunakan teknologi }\end{array}$ & 20,723 & 1,968 & Ha diterima \\
\hline
\end{tabular}

Berikut ini adalah hasil ringkasan pengujian hipotesis regresi berganda:

Tabel 8. Hasil Pengujian Hipotesis Regresi Berganda

\begin{tabular}{|c|c|c|c|c|c|}
\hline No & Hipc & & Fhitung & Ftabel & Keputusan \\
\hline \multirow[t]{2}{*}{3.} & $\mathrm{Ho}$ & $\begin{array}{lrr}\text { Kemudahan } & & \text { penggunaan } \\
\text { persepsian } & \text { dan } & \text { kegunaan } \\
\text { persepsian tidak } & \text { berpengaruh } \\
\text { terhadap sikap } & \text { menggunakan } \\
\text { teknologi } & & \end{array}$ & - & - & Ho ditolak \\
\hline & $\mathrm{Ha}$ & $\begin{array}{l}\text { Kemudahan penggunaan } \\
\text { persepsian dan kegunaan } \\
\text { persepsian berpengaruh terhadap } \\
\text { sikap menggunakan teknologi }\end{array}$ & 259,172 & 2,42 & Ha diterima \\
\hline \multirow{2}{*}{4.} & $\mathrm{Ho}$ & $\begin{array}{lrr}\text { Kemudahan } & \text { penggunaan } \\
\text { persepsian dan } & \text { kegunaan } \\
\text { persepsian tidak berpengaruh } \\
\text { terhadap minat } & \text { perilaku } \\
\text { menggunakan teknologi } & \end{array}$ & - & - & Ho ditolak \\
\hline & $\mathrm{Ha}$ & $\begin{array}{l}\text { Kemudahan penggunaan } \\
\text { persepsian dan kegunaan } \\
\text { persepsian berpengaruh terhadap } \\
\text { minat perilaku menggunakan } \\
\text { teknologi }\end{array}$ & 230,248 & 2,42 & Ha diterima \\
\hline 5. & $\mathrm{Ho}$ & penggunaan & - & - & Ho ditolak \\
\hline
\end{tabular}


Journal of Information Technology Ampera

Vol. 1, No. 1, April 2020 e-ISSN: 2774-2121

https://journal-computing.org/index.php/journal-ita/index

\begin{tabular}{|c|c|c|c|c|c|}
\hline & $\mathrm{Ha}$ & $\begin{array}{lr}\text { persepsian dan } & \text { kegunaan } \\
\text { persepsian tidak berpengaruh } & \text { teknologi } \\
\text { terhadap penggunaan } & \text { teknolon } \\
\text { sesungguhnya } & \\
\text { Kemudahan } & \text { penggunaan } \\
\text { persepsian dan } & \text { kegunaan } \\
\text { persepsian berpengaruh } & \text { terhadap } \\
\text { penggunaan } & \text { teknologi } \\
\text { sesungquhnya } & \end{array}$ & 73,989 & 2,42 & Ha diterima \\
\hline & $\mathrm{Ho}$ & \begin{tabular}{lcr} 
Kemudahan & \multicolumn{2}{c}{ penggunaan } \\
persepsian dan & sikap \\
menggunakan teknologi & tidak \\
berpengaruh terhadap minat & perilaku menggunakan teknologi
\end{tabular} & - & - & Ho ditolak \\
\hline 6. & $\mathrm{Ha}$ & 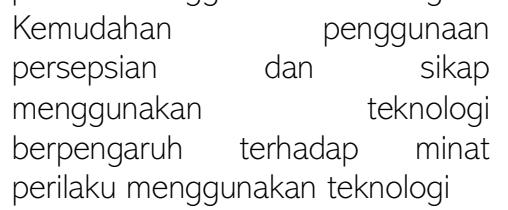 & 110,938 & 2,42 & Ha diterima \\
\hline 7. & $\mathrm{Ha}$ & $\begin{array}{l}\text { Kemudahan } \\
\text { persepsian, sikap menggunakan } \\
\text { teknologi dan minat perilaku } \\
\text { menggunakan teknologi tidak } \\
\text { berpengaruh terhadap penggunaan } \\
\text { teknologi sesungguhnya } \\
\text { Kemudahan penggunaan } \\
\text { persepsian, sikap menggunakan } \\
\text { teknologi dan minat perilaku } \\
\text { menggunakan teknologi tidak } \\
\text { berpengaruh terhadap penggunaan } \\
\text { teknologi sesungguhnya }\end{array}$ & 47,276 & 2,42 & Ho ditolak \\
\hline
\end{tabular}

\subsection{Pembahasan}

1. Kemudahan Penggunaan Persepsian terhadap Kegunaan Persespsian

Hasil uji regresi sederhana pada variabel kemudahan penggunaan persepsian terhadap kegunaan persepsian diperoleh nilai thitung $>$ ttabel $(12,850>$ $1,968)$ dan signifikasi $<0,05(0,000<0,05)$. Sehingga dapat diartikan bahwa kemudahan penggunaan persepsian berpengaruh terhadap kegunaan persepsian.

2. Kemudahan Penggunaan Persepsian terhadap Sikap menggunakan teknologi 
Hasil uji regresi sederhana pada variabel kemudahan penggunaan persepsian terhadap sikap menggunakan teknologi diperoleh nilai thitung $>$ ttabel $(20,723$ $>1,968)$ dan signifikasi $<0,05(0,000<0,05)$. Sehingga dapat diartikan bahwa kemudahan penggunaan persepsian berpengaruh terhadap sikap menggunakan teknologi.

3. Kemudahan Penggunaan Persepsian dan kegunaan persepsian terhadap Sikap menggunakan teknologi

Hasil uji regresi sederhana pada variabel kemudahan penggunaan persepsian dan kegunaan persepsian terhadap sikap menggunakan teknologi diperoleh nilai Fhitung > Ftabel $(259,172>2,42)$ dan signifikasi $<0,05(0,000<0,05)$. Sehingga dapat diartikan bahwa Sikap menggunakan teknologi berpengaruh terhadap kemudahan penggunaan persepsian dan kegunaan persepsian.

4. Kemudahan Penggunaan Persepsian dan kegunaan persepsian terhadap Niat Perilaku menggunakan Teknologi

Hasil uji regresi sederhana pada variabel kemudahan penggunaan persepsian dan kegunaan persepsian terhadap Niat Perilaku menggunakan Teknologi diperoleh nilai Fhitung > Ftabel $(230,248>2,42)$ dan signifikasi $<0,05$ $(0,000<0,05)$. Sehingga dapat diartikan bahwa Niat Perilaku menggunakan Teknologi berpengaruh terhadap kemudahan penggunaan persepsian dan kegunaan persepsian.

5. Kemudahan Penggunaan Persepsian dan kegunaan persepsian terhadap Penggunaan Teknologi Sesungguhnya

Hasil uji regresi sederhana pada variabel kemudahan penggunaan persepsian dan kegunaan persepsian terhadap Penggunaan Teknologi Sesungguhnya diperoleh nilai Fhitung $>$ Ftabel $(73,989>2,42)$ dan signifikasi $<0,05$ $(0,000<0,05)$. Sehingga dapat diartikan bahwa Sikap menggunakan teknologi berpengaruh terhadap kemudahan penggunaan persepsian dan kegunaan persepsian.

6. Kemudahan Penggunaan Persepsian dan Sikap menggunakan teknologi terhadap niat perilaku menggunakan teknologi

Hasil uji regresi sederhana pada variabel kemudahan penggunaan persepsian dan sikap menggunakan teknologi diperoleh terhadap niat menggunakan teknologi nilai Fhitung > Ftabel $(110,938>2,42)$ dan signifikasi $<0,05$ $(0,000<0,05)$. Sehingga dapat diartikan bahwa niat perilaku menggunakan 
teknologi berpengaruh terhadap kemudahan penggunaan persepsian dan sikap menggunakan teknologi.

7. Kemudahan Penggunaan Persepsian, Sikap menggunakan teknologi dan niat perilaku menggunakan teknologi terhadap penggunaan teknologi sesungguhnya

Hasil uji regresi sederhana pada variabel kemudahan penggunaan persepsian ,sikap menggunakan teknologi dan niat menggunakan teknologi terhadap penggunaan teknologi sesungguhnya diperolah nilai Fhitung > Ftabel $(47,276$ $>2,42)$ dan signifikasi $<0,05(0,000<0,05)$. Sehingga dapat diartikan bahwa Penggunaan teknologi sesungguhnya berpengaruh terhadap kemudahan penggunaan persepsian, sikap menggunakan teknologi dan niat perilaku menggunakan teknologi.

\section{KESIMPULAN}

Berdasarkan pembahasan Maka didapat kesimpulan sebagai berikut:

1) Berdasarkan analisis pada model TAM dan data kuesioner dari 236 responden maka dapat diketahui presentase tingkat penerimaan sistem informasi K-Exam dikatakan diterima sebesar 73,178\%. Hal ini menunjukkan bahwa sistem informasi K-Exam karate Lemkari di Lemkari Sumatera Selatan sudah diterima oleh responden. Tingkat penerimaan sistem informasi K-Exam juga dapat dilihat dari hasil perhitungan regresi yang dapat disimpulkan bahwa variabel sikap terhadap menggunakan teknologi, minat perilaku menggunakan teknologi dan penggunaan teknologi sesungguhnya berpengaruh terhadap kegunaan persepsian sedangkan kemudahan penggunaan persepsian berpengaruh terhadap kegunaan persepsian dan sikap menggunakan teknologi, serta sikap menggunakan teknologi berpengaruh terhadap minat perilaku menggunakan teknologi dan minat perilaku menggunakan teknologi berpengaruh terhadap penggunaan teknologi sesungguhnya.

2) Adapun faktor-faktor yang berpengaruh besar terhadap penerimaan sistem informasi K-Exam adalah kemudahan penggunaan persepsian dan sikap terhadap menggunakan teknologi. Semakin tinggi kemudahan penggunaan persepsian dan sikap terhadap menggunakan teknologi, maka semakin tinggi perilaku menggunakan sistem informasi K-Exam karate Lemkari di Lemkari Sumatera Selatan. Kegunaan persepsian, minat perilaku menggunakan teknologi, dan penggunaan teknologi sesungguhnya berpengaruh kecil terhadap penerimaan sistem informasi K-Exam karate Lemkari di Lemkari Sumatera Selatan. 


\section{DAFTAR PUSTAKA}

Alhamdu, 2016. Analisis Statistik Dengan Program SPSS. Palembang : Noer Fikri

Offset

Amirin, Tatang M. 2011. "Populasi dan sampel penelitian 4: Ukuran sampel rumus Slovin."

Chau, P.Y.K. "An Empirical Assessment of a Modified Technology Acceptance Model," Journal of Management Information System (13:2), 1996, pp. $185-204$

Davis, F.D. (1986) "Technology Acceptance Model for Empirically Testing New End-User Infromation System Theory and Results, " Unpublished Doctoral Dissertation, MIT., 1986.

Firdaus, Ali (2012), Analisa Penerimaan Penggunaan Sistem Informasi Akademik Menggunakan Hipotesis Technology Acceptance Model (TAM), Jurnal Akutandi, Bisnis, dan Informatika Vol.4 No.2 JuliDesember 2012, ISSN 2085-0042 